\title{
Biocontrol of grapevine aerial and root pathogens by Paenibacillus sp. strain B2 and paenimyxin in vitro and in planta
}

\author{
Zhipeng Hao ${ }^{\mathrm{a}, \mathrm{b}}$, Diederik Van Tuinen ${ }^{\mathrm{b}}$, Daniel Wipf ${ }^{\mathrm{b}}$, Léon Fayolle ${ }^{\mathrm{b}}$, Odile Chataignier ${ }^{\mathrm{b}}$, Xiaolin $\mathrm{Li}^{\mathrm{c}}$, \\ Baodong Chen ${ }^{\mathrm{a}}$, Silvio Gianinazzi ${ }^{\mathrm{b}}$, Vivienne Gianinazzi-Pearson ${ }^{\mathrm{b}}$, Marielle Adrian ${ }^{\mathrm{b}, *}$ \\ a State Key Laboratory of Urban and Regional Ecology, Research Center for Eco-Environmental Sciences, Chinese Academy of Sciences, 100085 Beijing, China \\ ${ }^{\mathrm{b}}$ Agroécologie, AgroSup Dijon, CNRS, INRA, Univ. Bourgogne Franche-Comté, 21065 Dijon cedex, France \\ ${ }^{\mathrm{C}}$ College of Resources and Environmental Sciences, China Agricultural University, 100193 Beijing, China
}

\section{H I G H L I G H T S}

- Paenibacillus sp. strain B2 and its antagonistic factor paenimyxin control grapevine pathogens.

- The bio-control effects are active against aerial or root pathogens in vitro or in planta.

- Paenimyxin acts as a biopesticide against the oomycete but does not trigger plant defense.

- Paenibacillus sp. strain B2 can induce plant defense gene expression.

\section{A R T I C L E I N F O}

\section{Article history:}

Received 31 October 2016

Revised 22 February 2017

Accepted 6 March 2017

Available online 12 March 2017

\section{Keywords:}

Paenibacillus

Paenimyxin

Grapevine pathogens

Biocontrol

Defence related genes

\begin{abstract}
A B S T R A C T
Paenibacillus sp. strain B2, isolated from the mycorrhizosphere of Sorghum bicolor, was previously shown to possess antagonistic activity against fungi and bacteria due to the secretion of the peptide paenimyxin. The effects of strain B2 and paenimyxin were assessed against grapevine pathogens as they potentially represent a non-polluting complement or an alternative biocontrol agent to existing disease management strategies. In this study, the effects of Paenibacillus sp. strain B2 and paenimyxin were analyzed in vitro or in planta on the aerial or root pathogens of grapevine Botrytis cinerea, Plasmopara viticola and Xiphinema index. The bacterium significantly reduced $B$. cinerea development in vitro, and substantially decreased $X$. index numbers in soil and gall formation in the root system of grapevine plants. In vitro, paenimyxin inhibited the mycelial growth of $B$. cinerea, the mobility of the zoospores of $P$. viticola and $X$. index activity. Supplying paenimyxin at the time of inoculation of leaf tissue with $P$. viticola decreased infection sites, compared to application prior to fungal inoculation. Using the $P$. viticola/grapevine pathosystem, we showed that paenimyxin acts as a biopesticide against the oomycete but does not trigger plant defense. Conversely, Paenibacillus sp. strain B2 can induce the expression of the defense genes $\mathrm{CHI}$ (chitinase), $\mathrm{PR}-3$ (proteinase inhibitor) and LOX (lipoxygenase). Altogether, the results obtained highlight the interest of Paenibacillus sp. strain B2 and paenimyxin for the biocontrol of different grapevine diseases.
\end{abstract}

(c) 2017 Elsevier Inc. All rights reserved.

\section{Introduction}

Grapevine (Vitis spp.) is susceptible to several pathogenic microorganisms including bacteria, viruses, oomycetes, fungi and nematodes. Botrytis cinerea is the fungus responsible for grey mold, a disease known to cause severe qualitative and quantitative damage of the grape harvest. Chemical fungicides are problematic because of the risks of non-target impacts appearing and the establishment of resistant Botrytis sp. strains (Leroch et al., 2011), as well

\footnotetext{
* Corresponding author at: UMR Agroécologie, INRA, 7 rue Sully, BP 86510, 21065 Dijon cedex, France.

E-mail address: marielle.adrian@u-bourgogne.fr (M. Adrian).
}

as the presence of residues in wines (Edder et al., 2009). Biological control strategies against $B$. cinerea have been developed but remain poorly used as their efficacy under field conditions is often limited (Elmer and Reglinski, 2006; Hahn, 2014). Another serious grapevine disease, downy mildew, is caused by the oomycete Plasmopara viticola. This pathogen enters the plant via stomata and colonizes inner leaf tissues by developing an intercellular mycelium before emerging through other stomata for sporulation. As the life cycle of this oomycete is reduced to one week in optimal temperature and humidity conditions, the control of the disease requires numerous treatments, especially in vineyards subjected to rainy springs. Numerous chemical fungicides have been developed, but some of them lead to the development of resistant strains (Nanni 
et al., 2016). Copper is practically the unique solution in organic farming as all other alternatives to chemicals are not efficient enough in situations of middle to high disease pressure. However, the secondary effect of copper accumulation in soils is problematic (Brunetto et al., 2014). The Grapevine Fanleaf Virus (GFLV) is responsible for fanleaf disease, one of the most detrimental grapevine diseases worldwide, with yield decreases up to $80 \%$ and an alteration in berry quality (Andret-Link et al., 2004; Martelli, 2012). The ectoparasitic root-feeding nematode Xiphinema index, which also has direct pathogenicity, is the vector for the transmission of GFLV. Xiphinema sp. can be difficult to control using chemical nematicides, which may have a poor penetration potential in some soils, a high acute toxicity and a detrimental effect on beneficial nontarget soil organisms (Barker and Koenning, 1998; Abawi and Widmer, 2000). In addition, their use is now forbidden in some countries. Nematicidal plants have been identified but are often not efficient enough (Aballay et al., 2001), and the recommended 10 -year fallow therefore remains the most efficient strategy (Demangeat et al., 2005), although highly impractical.

Research over the past decades has led to a significant improvement in knowledge about the beneficial effects of antagonistic microorganisms (Cook, 2000), which can offer protection against insect herbivores and phytopathogens, including bacteria, fungi, nematodes, and viruses (Gu et al., 2010; Han et al., 2017; Saophuong et al., 2014). These act as antagonists against pathogens through competition (Bloemberg and Lugtenberg, 2001), production of antibiotics, extracellular enzymes or metabolites (Ongena and Jacques, 2008; Degenkolb and Vilcinskas, 2016a,b), and induced systemic resistance (ISR) (Shoresh et al., 2010; Schouteden et al., 2015). In a previous study the gram-positive bacterium Paenibacillus sp. strain B2, isolated from the mycorrhizosphere of Sorghum bicolor inoculated with Glomus mosseae (Budi et al., 1999), was shown to possess antagonistic activity towards soil-borne fungal pathogens partly due to the secretion of hydrolytic enzymes (Budi et al., 2000). In addition, Paenibacillus sp. strain B2 secretes the peptide paenimyxin, an antagonistic factor active against fungi as well as gram-positive and gram-negative bacteria (Selim et al., 2005). When applied to soil, paenimyxin transiently impacts the genetic structure and density of soil bacterial communities (Selim et al., 2007). Paenimyxin also induces defense reactions in Medicago truncatula, especially the production of hydrogen peroxide and the expression of defense-related genes (Selim et al., 2010). Previous papers reported that the mode of action of Paenibacillus species against microorganisms involves the induction of plant defense. For example, Paenibacillus alvei $\mathrm{K} 165$ protects Arabidopsis plantlets against Verticillium dahliae through both salicylate and jasmonatedependent pathways (Gkizi et al., 2016; Sang et al., 2014). We therefore wanted to know if Paenibacillus strain B2 and paenimyxin were able to trigger grapevine defense mechanisms.

The present study was conducted to assess the efficacy of Paenibacillus sp. strain B2 and paenimyxin against the problematic grapevine pathogens $B$. cinerea (fungus), $P$. viticola (oomycete), and $X$. index (nematode). The potential of Paenibacillus sp. strain B2 and paenimyxin in biocontrol strategies against grapevine pathogens offers a non-polluting complement or alternative to existing strategies of grapevine disease management in order to reduce the use of chemical pesticides.

\section{Material and methods}

\subsection{Biological material}

Cuttings of grapevine cv. Marselan (Cabernet sauvignon $\times$ Grenache) plants and of the rootstock SO4 $(V$. berlandieri $\times V$. riparia) were used for shoot and root pathogen tests, respectively. Marse- lan plants were obtained from herbaceous cuttings placed in individual pots $(10 \times 10 \mathrm{~cm})$ containing a mixture of blond peat, sand, and perlite $(4: 1: 1, \mathrm{vol} / \mathrm{vol} / \mathrm{vol})$. They were grown in a glasshouse at a temperature of 24 and $18{ }^{\circ} \mathrm{C}$ (day and night, respectively) with a $16 \mathrm{~h}$ light photoperiod at a relative humidity $(\mathrm{RH})$ of $70 \pm 10 \%$ until they developed six leaves, as previously described (Allègre et al., 2007). Plants were watered daily and a fertilizing solution (PlantProd, Puteaux SA, France) was supplemented once a week. SO4 plants were grown in vitro in Murashige and Skoog medium (Murashige and Skoog, 1962) in a growth cabinet at $24^{\circ} \mathrm{C}$ with a $16 \mathrm{~h}$ light photoperiod.

B. cinerea isolate BO5.10 (Bessire et al., 2007) was grown on PDA (potato dextrose agar; Difco). Conidia were harvested in water, filtered through glass wool and suspended in 1/2 PDB (potato dextrose broth; Difco). The suspension was adjusted to a concentration of $5.10^{4}$ spores per milliliter for bioassays.

$P$. viticola was isolated from a Burgundy vineyard and maintained on $V$. vinifera L. cv. Marselan herbaceous cuttings in the glasshouse as previously described (Trouvelot et al., 2008). The plants were placed in the dark at $100 \% \mathrm{RH}$ overnight in order to induce sporulation. Sporangia were collected from the abaxial leaf side using a brush and suspended in distilled water. The concentration was adjusted to $10^{4}$ sporangia per milliliter using a Malassez hemacytometer before inoculation.

$X$. index Thorne and Allen (1950) was collected in a Burgundy vineyard and reared under greenhouse conditions on Ficus carica L. to provide a permanent source of virus-free nematodes (Coiro and Brown, 1984). Nematodes were extracted from soil using the Baermann funnel and sieving procedure as previously described (Hao et al., 2012). Active nematodes were recovered in the bottom of the Petri dish after $48 \mathrm{~h}$; adults and juveniles were counted in the final suspension with an etched grid. Nematode inoculation consisted of dispensing a water suspension of 100 nematodes (10 nematodes $\mathrm{mL}^{-1}$ ) into evenly spaced $6-8 \mathrm{~cm}$ deep holes around plants. Non-inoculated plants received an equivalent volume of water.

Paenibacillus sp. strain B2 (Budi et al., 1999) was grown in liquid Luria-Bertani (LB) culture medium at $28^{\circ} \mathrm{C}$, agitated at $125 \mathrm{rpm}$ for $20 \mathrm{~h}$ to reach a stationary phase. Escherichia coli strain MRAP2 was cultured at $37^{\circ} \mathrm{C}$ on LB culture medium.

The antagonistic peptide paenimyxin was purified from the bacterial culture medium by cation-exchange, reverse-phase, and size exclusion chromatography as previously described (Selim et al., 2005).

\subsection{Analysis of antagonistic activities of Paenibacillus sp. strain B2}

To test the antagonistic activity of Paenibacillus sp. strain B2 against B. cinerea BO5.10, a single drop of Paenibacillus sp. strain $\mathrm{B} 2$ culture, or of $E$. coli as negative control, was inoculated on each side of a $9 \mathrm{~mm}$ petri dish containing PDA medium, and incubated 3 days at $20^{\circ} \mathrm{C}$ prior to inoculation in the center of a disk $(\sim 2 \mathrm{~mm}$ in diameter) of $B$. cinerea from a PDA culture. Mycelial growth of the pathogen was observed after 1 week. The experiment was repeated 3 times.

The effect of Paenibacillus sp. strain B2 on X. index mortality was tested in vitro in microtitration plates (Sigma-Aldrich, Milan, Italy). A volume $(0.5 \mathrm{ml})$ of a Paenibacillus sp. strain B2 suspension $\left(0,10^{6}\right.$, $10^{7}, 10^{8}, 10^{9} \mathrm{CFU} \mathrm{ml}^{-1}$ ) was added to 15 adult females. Nematodes were then observed under a light microscope at 1, 2, 4, 8, 24 and every 8 or $16 \mathrm{~h}$ intervals for $120 \mathrm{~h}$. The active/inactive nematodes were recognized by the reaction of their body to pricking with soft fibers. The experimental design was randomized, with each concentration replicated four times, and each experiment was repeated at least twice with separate controls. 
The effect of Paenibacillus sp. strain B2 on X. index development in planta was evaluated on SO4 grapevine plants in a two factorial experiment, with a bacterial treatment (inoculation with Paenibacillus sp. strain B2) and a pathogen treatment (inoculation with $X$. index). Four conditions were used as follows: 1, control (no Paenibacillus sp. strain B2 and no X. index) (CK); 2, inoculation with Paenibacillus sp. strain B2 at repotting time (B2); 3, inoculation with $X$. index (Xi) 1 week after repotting; 4, inoculation with Paenibacillus sp. strain $\mathrm{B} 2$ at repotting time and $X$. index 1 week later (B2 + Xi). Glass jars $(750 \mathrm{ml})$ were filled with $240 \mathrm{ml}$ of a 1:1 (v/v) mix of sterilized $\left(180^{\circ} \mathrm{C}, 6 \mathrm{~h}\right)$ terragreen ${ }^{\circledR}$ (OilDri-US special, Mettman, Germany) and a $\gamma$-irradiated clay-loam soil (pH 7.96 (soil:water, $1: 2.5), \quad 14.4 \mathrm{~g} \mathrm{~kg}^{-1}$ organic matter, $67 \mathrm{mg} \mathrm{kg}^{-1}$ Olsen-P, $1.46 \mathrm{mg} \mathrm{kg}^{-1} \quad \mathrm{NaOH}$-extractable $\mathrm{N}, \quad 0.241 \mathrm{~g} \mathrm{~kg}^{-1} \quad \mathrm{NH}_{4} \mathrm{Ac}-$ exchangeable $\mathrm{K})$ and autoclaved $\left(120^{\circ} \mathrm{C}, 30 \mathrm{~min}\right)$ twice at $24 \mathrm{~h}$ interval. Ten microliters of a bacterial suspension $\left(10^{9} \mathrm{cfu} \mathrm{ml}^{-1}\right.$ in $0.1 \mathrm{mM} \mathrm{MgSO}_{4}$ ) were added to $65 \mathrm{ml}$ sterile Long-Ashton nutrient solution, and the mixture supplied to each jar to obtain $60 \%$ of water holding capacity of the growth medium. Ten microliters $0.1 \mathrm{mM} \mathrm{MgSO}_{4}$ without bacteria served as control. After each treatment, one in vitro-produced SO4 plant (with two leaves and about $2 \mathrm{~cm}$ long roots without agar) was transplanted into each jar, and allowed to establish for 1 week in an illumination incubator at $24{ }^{\circ} \mathrm{C}$ with a $16 \mathrm{~h}$ light photoperiod. Nematodes were then inoculated at the root level as indicated above (100 nematodes/pot). Five replicates per treatment were harvested at 35 days after inoculation with $X$. index. Shoot fresh weight was recorded. The number of nematodes in the soil and the number of galls on roots were determined as previously described (Xu et al., 2008). Root samples were weighed, ground in liquid nitrogen and stored at $-80^{\circ} \mathrm{C}$ until gene expression analysis.

\subsection{Analysis of antagonistic activities of paenimyxin}

\subsubsection{Effect on Botrytis cinerea}

The suppressive effect of paenimyxin on mycelial growth of $B$. cinerea was investigated in vitro according to Bessire et al. (2007). B. cinerea conidia $\left(10^{4}\right.$ spores $\left.\mathrm{ml}^{-1}\right)$ were mixed with different concentrations of paenimyxin $\left(0,5,10\right.$, and $\left.50 \mu \mathrm{g} \mathrm{ml}^{-1}\right)$, deposited on a glass slide at $100 \%$ relative humidity and were incubated for $12 \mathrm{~h}$ at $20^{\circ} \mathrm{C}$. Conidia germination and mycelial growth were evaluated by microscopy (Leica DFC 490, Leica Microsystems) and following image analyses using the Leica Application Suite 3.1 (Leica Microsystems). Experiments were performed with five replicates per condition and were independently repeated at least 3 times.

\subsubsection{Effect on Plasmopara viticola}

The effects of paenimyxin on the mobility of $P$. viticola zoospores were assessed in vitro as described by Pezet et al. (2004). Briefly, sporangia of $P$. viticola were collected and suspended in distilled water at a concentration of $10^{5} \cdot \mathrm{ml}^{-1}$. After $1 \mathrm{~h}$ of gentle agi- tation at room temperature, zoospores were released from about $50 \%$ of the sporangia, leading to a suspension of $0.510^{5} \mathrm{~mL}^{-1}$ mobile zoospores. Paenimyxin was added to the zoospore suspension at final concentrations of $0,5,10$ and $50 \mu \mathrm{g} \mathrm{ml}^{-1}$, respectively. Five minutes after the addition of paenimyxin, the number of mobile zoospores was counted in an area of $0.11 \mathrm{~mm}^{2}$ during a viewing period of $30 \mathrm{~s}$ under a light microscope (Leica-Leitz, magnification $60 \times$ ). For each paenimixin concentration, the measurement was repeated 5 times and the bioassays were repeated 3 times independently.

The effects of paenimyxin on the infection of grapevine leaves by $P$. viticola were investigated using three different experimental procedures. Discs (10 $\mathrm{mm}$ diameter) were punched out from mature leaves and placed in a Petri dish on wet filter paper. For the first set of experiments (called "PPv"), one droplet $(30 \mu \mathrm{l})$ of a mixture of a $10^{4} \cdot \mathrm{mL}^{-1} P$. viticola sporangia suspension and a paenimyxin solution (see below) were deposited on the abaxial side of the leaf discs, and then droplets removed using laboratory tissues $24 \mathrm{~h}$ later. For the second set of experiments (called "PdPv"), droplets of paenimyxin ( $30 \mu \mathrm{l})$ were deposited on the abaxial side of leaf discs and left for $48 \mathrm{~h}$ to allow paenimyxin penetration into leaf tissues. Discs were then rinsed three times in $50 \mathrm{mM}$ phosphate buffer $(\mathrm{pH} 7.0)$ to remove the residual paenimyxin and inoculated with a $30 \mu \mathrm{l}$ droplet of a $10^{4} \cdot \mathrm{mL}^{-1} \mathrm{P}$. viticola sporangia suspension for $24 \mathrm{~h}$. For the third experiment set (called "PfPv"), leaf discs were incubated in the paenimyxin solution (flotation) in Petri dishes for $48 \mathrm{~h}$, rinsed three times in phosphate buffer ( $\mathrm{pH} 7.050 \mathrm{mM}$ ) to remove the residual of paenimyxin, and inoculated with 1 droplet of a $10^{4} \cdot \mathrm{ml}^{-1} P$. viticola sporangia suspension for $24 \mathrm{~h}$. Paenimyxin was applied at final concentrations of 0 , $0.25,0.4,2.5,4$ or $25 \mu \mathrm{g} \mathrm{ml}^{-1}$. The level of $P$. viticola sporulation was determined at 6 days post inoculation (dpi) by determination of the percentage of sporulating leaf area. Experiments were repeated three times.

\subsubsection{Effect on Xiphinema index}

The in vitro tests of the effects of paenimyxin on $X$. index mortality were carried out in microtitration plates (Sigma-Aldrich, Milan, Italy). $0.5 \mathrm{ml}$ of paenimyxin (final concentration of $0.4,2,10$ or $50 \mu \mathrm{g} \mathrm{ml}^{-1}$ ) or osmosed water as control was added to 15 adult females. Nematodes were then observed under a light microscope at every 8 or $16 \mathrm{~h}$ intervals for $120 \mathrm{~h}$. The active/inactive nematodes were recognized by their response to pricking of their body with soft fibers. The experimental design was randomized, each concentration was replicated four times, and each experiment was repeated at least twice with separate controls.

\subsection{Analysis of defense gene expression}

The expression of the defense-related genes chitinase $1 \mathrm{~b}(\mathrm{CHI}$, Busam et al., 1997), phenylalanine ammonia lyase (PAL), stilbene synthase 1 (STS, Sparvoli et al., 1994), glutathione-S-transferase

Table 1

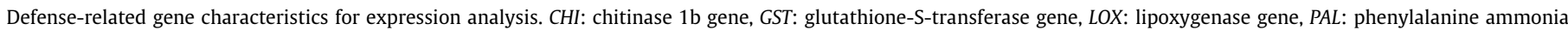

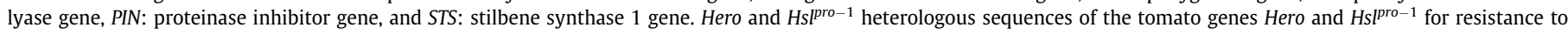
nematodes (XM_002265532.1 and XM_002268530.1).

\begin{tabular}{|c|c|c|c|c|c|c|c|}
\hline Gene & $\begin{array}{l}\text { Accession } \\
\text { number }\end{array}$ & Forward primer & Reverse primer & $\begin{array}{l}\text { Annealing } \\
{ }^{\circ} \mathrm{C}\end{array}$ & $\begin{array}{l}\text { Amplicon size } \\
\text { (bp) }\end{array}$ & $\begin{array}{l}\mathrm{r}^{2} \text { of calibration } \\
\text { curve }\end{array}$ & $\begin{array}{l}\text { PCR } \\
\text { efficiency }\end{array}$ \\
\hline $\mathrm{CHI}$ & Z54234 & CCСAAGCCTTCCTGCCATA & TGTGATAACACCAAAACCGGG & 60 & 96 & 0.997 & 0.998 \\
\hline GST & AY156048 & TGCATGGAGGAGGAGTTCGT & CAAGGCTATATCCCCATTTTCTTC & 60 & 98 & 0.996 & 0.995 \\
\hline LOX & AY159556 & СССТTCTTGGCATCTCCСТTA & TGTTGTGTCCAGGGTCCATTC & 56 & 101 & 0.994 & 0.933 \\
\hline$P A L$ & X75967 & TCCTCCCGGAAAACAGCTG & ТССТССАААТGССТСАААТСА & 56 & 101 & 0.997 & 0.897 \\
\hline PIN & AY156047 & AGTTCAGGGAGAGGTTGCTG & CACCAACCCAATGAGTCTATCC & 59 & 185 & 0.996 & 0.974 \\
\hline STS & X76892 & AGGAAGCAGCATTGAAGGCTC & TGCACCAGGCATTTCTACACC & 55 & 101 & 0.997 & 0.920 \\
\hline HERO & XM_002265532.1 & CGGAAGAAAATGGGATGGAAGAG & ATGAGCAATAAGTCGGCGAGGG & 59 & 188 & 0.993 & 0.950 \\
\hline HS & XM_002268530.1 & GCTGTACCGCGAAAAGGTAG & AGATTTGAGACAACGAGTCC & 57 & 188 & 0.997 & 0.932 \\
\hline
\end{tabular}


(GST), lipoxygenase (LOX) and pathogenesis-related protein PR-6 (PIN) (Aziz et al., 2003), of the heterologous sequences of the tomato genes Hero and $H s 1^{\text {pro-1 }}$ for resistance to nematodes (XM_002265532.1and XM_002268530.1), and of the constitutively-expressed reference gene encoding GAPDH (Reid et al., 2006) was studied in root samples (Table 1). Three biological repetitions were used for each treatment, and PCRs were carried out in triplicate per sample. RNA extraction and precipitation were performed as previously described (Hao et al., 2012). RNA quantity and quality were estimated by $260 / 280 \mathrm{~nm}$ absorbance and $1 \%$ denaturating gel electrophoresis. cDNA synthesis was performed with the M-MLV reverse transcriptase kit (Invitrogen) following the manufacturer's recommendations. Primers were defined for transcript quantification of selected genes and PCR conditions according to Hao et al. (2012). Transcripts were quantified using the ABsolute ${ }^{\mathrm{TM}}$ QPCR SYBR green ROX mix (ABgene, Epsom, UK) and an ABI PRISM 7900 apparatus (Applied BioSystems, Foster City, CA, USA). Real time PCR was carried out in $1 \mu \mathrm{l}$ of $100 \times$ diluted cDNA as template in a final volume of $20 \mu$ containing $1 \times$ SYBR green mix, and $20 \mathrm{nM}$ of each gene-specific primer, as recommended by the manufacturer. PCR cycling consisted of an initial denaturation step at $94{ }^{\circ} \mathrm{C}$ for $5 \mathrm{~min}$, followed by 40 cycles at $94{ }^{\circ} \mathrm{C}$ for $30 \mathrm{~s}, 58^{\circ} \mathrm{C}$ for $30 \mathrm{~s}$, and $72{ }^{\circ} \mathrm{C}$ for $30 \mathrm{~s}$ (Applied Biosystems). Standard amplification curves were determined from duplicate samples of plasmid DNA [TOPO plasmids containing each amplicon were quantified by UV absorbance spectroscopy (Eppendorf BioPhotometer) and linearized by NotI (Promega) digestion] at $10^{2}, 10^{3}, 10^{4}, 10^{5}, 10^{6}$, and $10^{7}$ copies. A melting curve analysis was included at the end of each PCR run in order to verify amplification of each target cDNA. Quantification cycle $(\mathrm{Cq})$ were analyzed by SDS 2.2 software (Applied Biosystems, Foster City, CA, USA) and target-gene expression data were plotted as $2^{(40-\mathrm{Cq})} / 10$, as explained in Czechowski et al. (2004), and normalized using the internal reference $G A D P H$ gene. PCR amplification efficiency $\left(10^{-1 / \text { slope }}-1\right)$ were determined from the slope of the log-linear portion of the calibration curve, when the logarithm of the initial template concentration is plotted on the $\mathrm{x}$ axis and $\mathrm{Cq}$ is plotted on the $\mathrm{y}$ axis (Table 1 ).

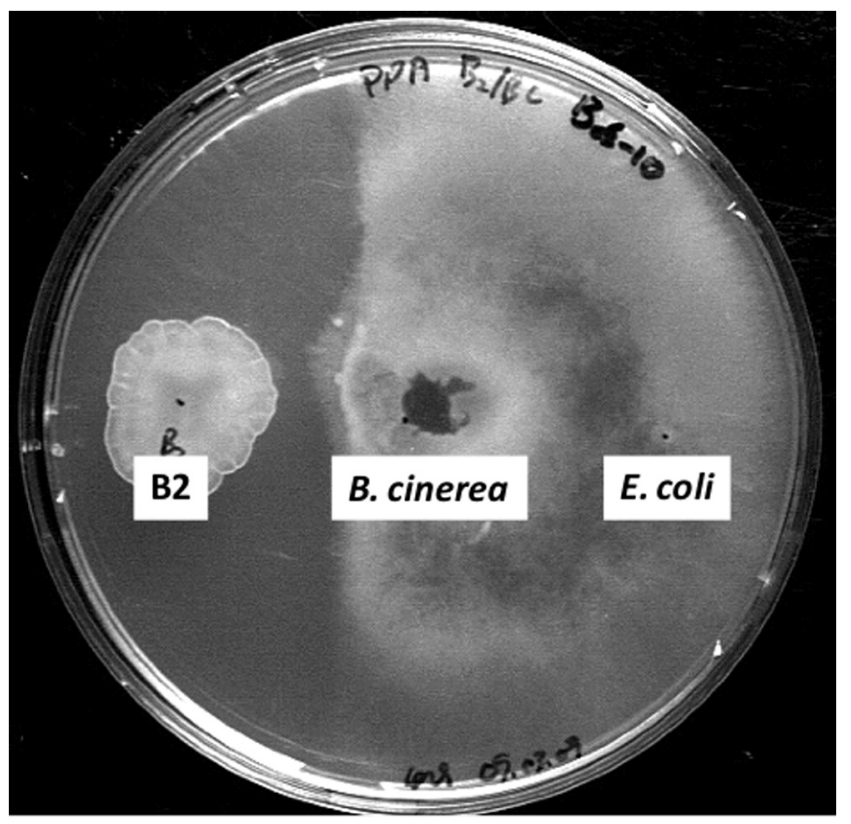

Fig. 1. Antagonistic activity of Paenibacillus sp. strain B2 (B2) against Botrytis cinerea in vitro, compared with the reference bacterial strain E. coli MRAP2. Single colonies of both bacteria were inoculated on opposite sides of a Petri dish three days before $B$. cinerea inoculation. The photograph was taken one week after $B$. cinerea inoculation.

\subsection{Data analysis}

Statistical analysis of the data was carried out by analysis of variance (ANOVA) using the SPSS package (version 13.0, SPSS Inc., USA). Significant differences between means were established by calculation of LSD at the 5\% level. Furthermore, two-way ANOVA was performed to compare the effects of Paenibacillus sp. strain B2 and $X$. index inoculation on plant growth, nematode development and gene expression using SPSS (version 13.0, SPSS Inc., USA).

\section{Results}

3.1. Inhibitory effect of Paenibacillus sp. strain B2 and paenimyxin on Botrytis cinerea growth

Paenibacillus sp. strain B2 inhibited the growth of B. cinerea, as indicated by the formation of clear zones surrounding the bacterial colony in plate assays (Fig. 1). Conversely, no effect was observed for $E$. coli which was included as negative control.

The peptide paenimyxin significantly reduced the mycelium growth of $B$. cinerea. At the concentrations of 5 and $10 \mu \mathrm{g} \mathrm{ml}^{-1}$, the percentages of inhibition were $54 \%$ and $81 \%$, respectively, when

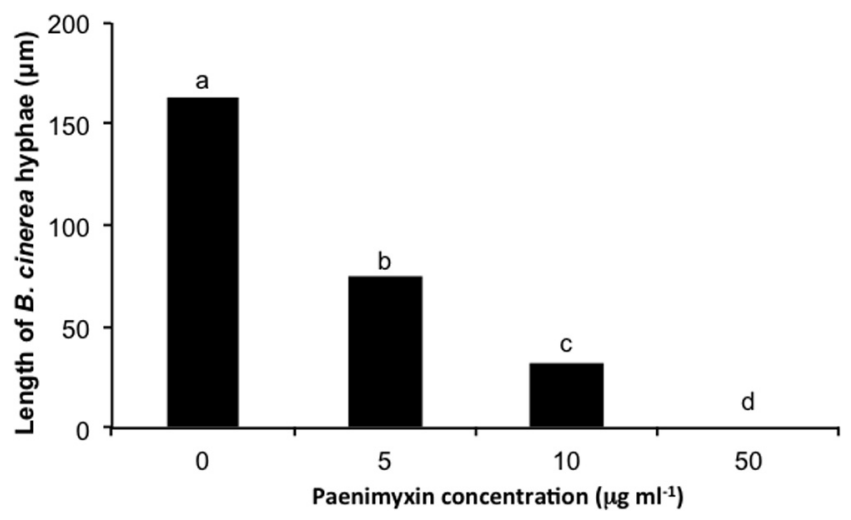

Fig. 2. Effect of paenimyxin on Botrytis cinerea development in vitro. Different concentrations of paenimyxin ( 0 to $50 \mu \mathrm{g} \mathrm{mL}^{-1}$ ) were added to a conidial suspension $\left(10^{4}\right.$ spores. $\left.\mathrm{ml}^{-1}\right)$ of the fungus on slides. Observations were made using a microscope equipped with a camera and mycelium length was determined using the Leica Application Suite 3.1 (Leica Microsystems).

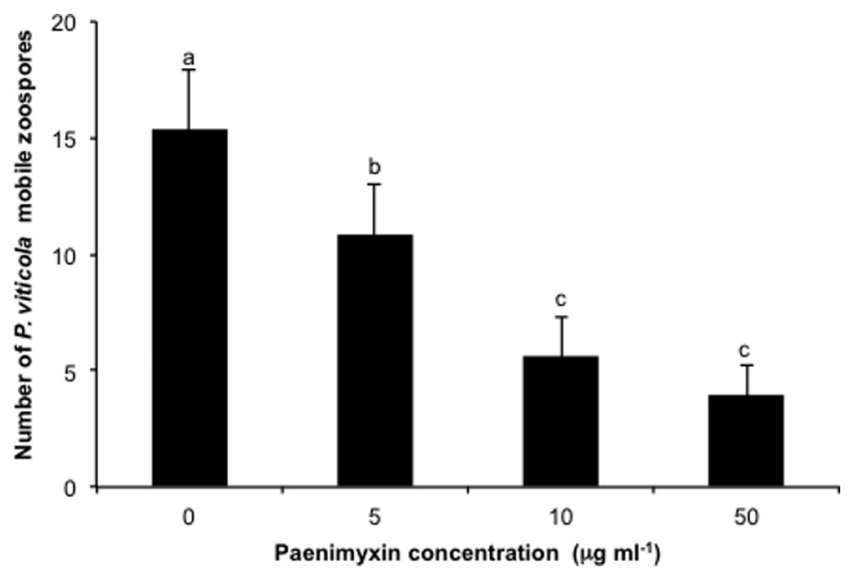

Fig. 3. Effect of paenimyxin on Plasmopara viticola zoospore mobility in vitro. Zoospores were incubated with different paenimyxin concentrations ( 0 to $50 \mu \mathrm{g} \mathrm{ml}^{-1}$ ) and observed by microscopy. The number of active zoospores was counted on a surface of $0.11 \mathrm{~mm}^{2}$ during $30 \mathrm{~s}$ under a light microscope (Leica-Leitz, magnification $60 \times$ ). 
compared to water (Fig. 2). At concentrations higher than $20 \mu \mathrm{g} \mathrm{ml}^{-1}$, paenimyxin completely inhibited the mycelial growth.

\subsection{Antagonistic effect of paenimyxin on Plasmopara viticola in vitro and in planta}

Paenimyxin significantly reduced the mobility of $P$. viticola zoospores. At 5, 10 and $50 \mu \mathrm{g} \cdot \mathrm{ml}^{-1}$, the number of mobile zoospores was reduced by about $30 \%, 64 \%$ and $74 \%$, respectively (Fig. 3). The effect of paenimyxin on P. viticola infection of leaf tissue was highly dependent on the way of application (Fig. 4). When applied together with the sporangia suspension (PPv), paenimyxin strongly inhibited $P$. viticola development and sporulation; sporulation was scarce at the concentration of $0.25 \mu \mathrm{g} \mathrm{ml}^{-1}$ and absent at $2.5 \mu \mathrm{g} \mathrm{ml}^{-1}$ and higher concentrations. When applied by flotation (Pf-Pv) before inoculation, paenimyxin was less active, although sporulation was reduced by $>60 \%$ at 4 and $25 \mu \mathrm{g} \mathrm{ml}^{-1}$. Finally, when applied as droplets (Pd-Pv) before inoculation, paenimyxin was no longer active, even at the concentration of $25 \mu \mathrm{g}$. $\mathrm{ml}^{-1}$.

\subsection{Effects of Paenibacillus sp. strain B2 and paenimyxin on X. index activity}

Inoculation of SO4 plants with Paenibacillus sp. strain B2 promoted root biomass, while nematode inoculation had no effect at

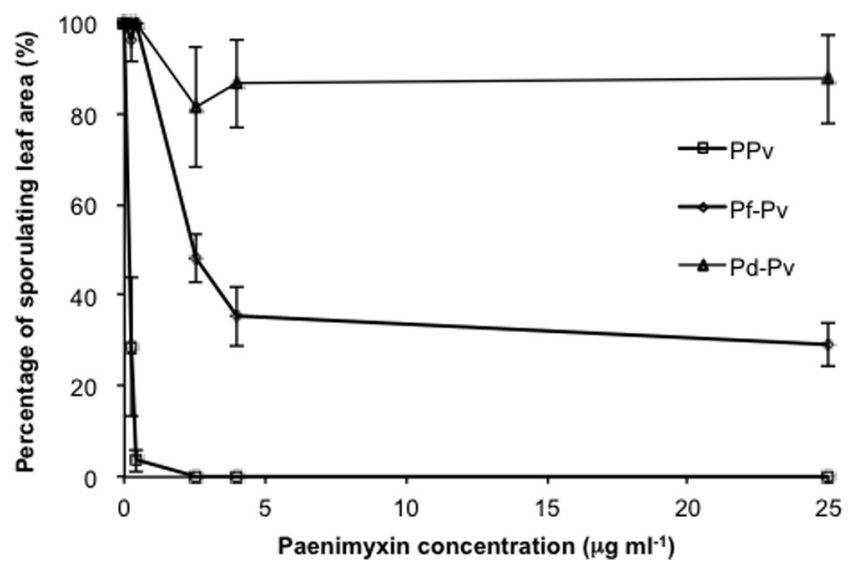

Fig. 4. Effect of paenimyxin on Plasmopara viticola development in planta. The abaxial side of foliar discs of Marselan grapevine was treated with a droplet of a mixture of paenimyxin and $P$. viticola sporangia suspension $(\mathrm{PPv})$, a droplet of paenimyxin for $24 \mathrm{~h}$ prior to inoculation with a P. viticola sporangia suspension (Pd$\mathrm{Pv}$ ), or paenimyxin by flotation for $48 \mathrm{~h}$ before inoculation with a $P$. viticola sporangia suspension (Pf-Pv). Paenimyxin was added at concentrations of $0,0.25$, $0.4,2.5,4$ or $25 \mu \mathrm{g} \mathrm{ml}^{-1}$. Values correspond to the percentage area of leaf discs showing $P$. viticola sporulation.
35 dpi (Table 2). This growth promoting effect was not affected by inoculation with $X$. index. Shoot biomass showed a similar trend, and inoculation or co-inoculation with $X$. index had no significant effect, compared with the control treatment. No nematode infection was observed in the non-inoculated control treatment whilst in the nematode-inoculated control plants, $X$. index successfully developed (about 100 nematodes/jar) and infected roots, as indicated by the occurrence of galls (about 14 galls/plant). Application of Paenibacillus sp. strain B2 significantly decreased X. index development in planta, as indicated by a significant reduction in the number of galls per plant (twice lower than inoculated control) and nematodes in soil (Table 2).

The activity of nematodes decreased slightly in vitro during the time course of the experiment (Fig. 5A). Application of Paenibacillus
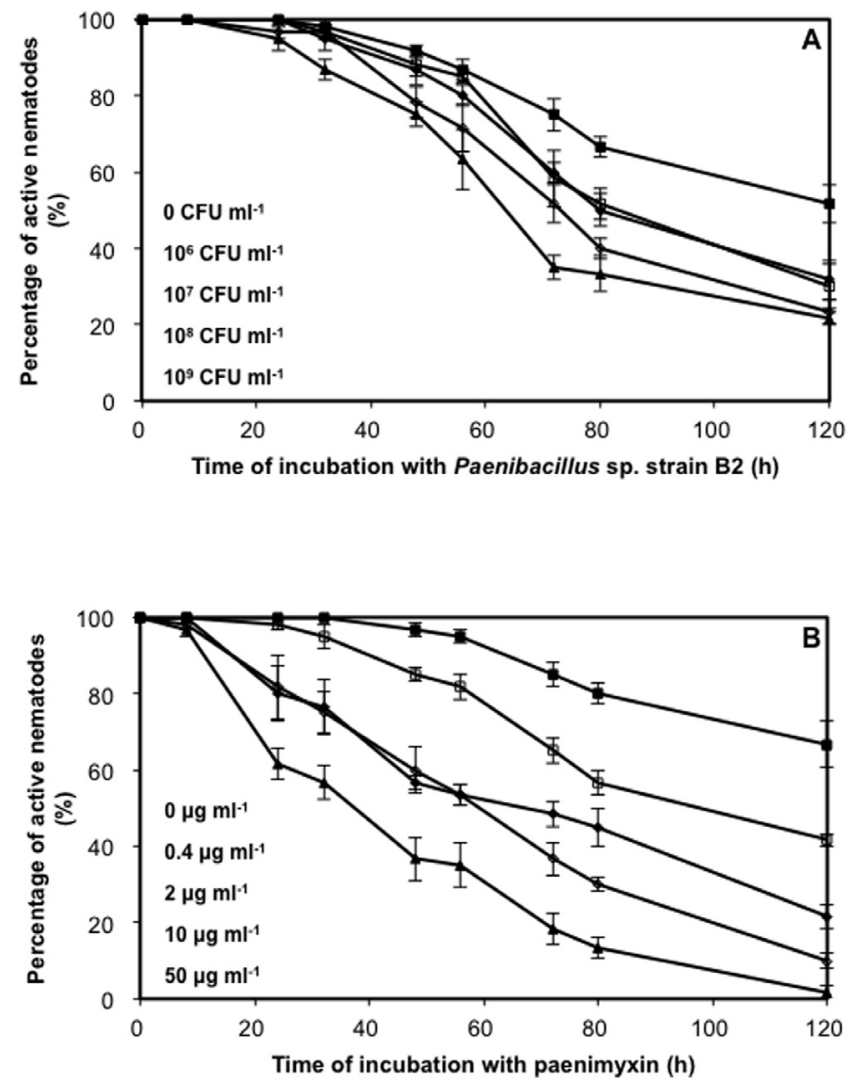

Fig. 5. Effects of Paenibacillus sp. strain B2 (A) and paenimyxin (B) on Xiphinema index activity. A bacterial suspension $\left(0,10^{6}, 10^{7}, 10^{8}\right.$ or $10^{9} \mathrm{CFU} \mathrm{ml}^{-1}$ ) or paenimyxin $\left(0,0.4,2,10\right.$ or $\left.50 \mu \mathrm{g} \mathrm{ml}^{-1}\right)$ were added to $15 \mathrm{X}$. index adult females. The active/inactive nematodes were recognized by the response of their body to pricking with soft fibers from 0 to $120 \mathrm{~h}$ incubation.

Table 2

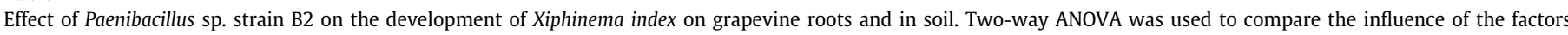

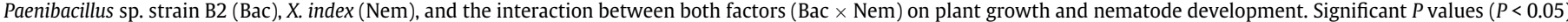

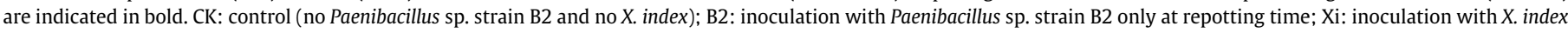
only; and B2 + Xi: inoculation with Paenibacillus sp. strain B2 at repotting time and with X. index one week later.

\begin{tabular}{|c|c|c|c|c|}
\hline Treatments & Shoot fresh weight (g) & Root fresh weight (g) & Gall number/plant & Nematode number/jar \\
\hline CK & $1.24 \mathrm{~b}$ & $0.42 \mathrm{~b}$ & $0.0 \mathrm{c}$ & $0.0 \mathrm{c}$ \\
\hline B2 & $1.41 \mathrm{a}$ & $0.54 \mathrm{a}$ & $0.0 \mathrm{c}$ & $0.0 \mathrm{c}$ \\
\hline $\mathrm{Xi}$ & $1.31 \mathrm{ab}$ & $0.40 \mathrm{~b}$ & $14.0 \mathrm{a}$ & $101.2 \mathrm{a}$ \\
\hline $\mathrm{B} 2+\mathrm{Xi}$ & $1.34 \mathrm{ab}$ & $0.55 \mathrm{a}$ & $7.2 \mathrm{~b}$ & $73.7 \mathrm{~b}$ \\
\hline \multicolumn{5}{|l|}{ Factors } \\
\hline $\mathrm{Bac}$ & 0.012 & $<0.001$ & 0.001 & 0.010 \\
\hline Nem & 0.932 & 0.613 & $<0.001$ & $<0.001$ \\
\hline $\mathrm{Bac} \times \mathrm{Nem}$ & 0.055 & 0.943 & 0.001 & 0.010 \\
\hline
\end{tabular}


sp. strain B2 induced a decrease in the proportion of active nematodes from 24,48 , and $72 \mathrm{~h}$ post treatment for concentrations of $10^{9}, 10^{8}$, and $10^{7}-10^{6}$ bacteria $\mathrm{ml}^{-1}$, respectively (Fig. $5 \mathrm{~A}$ ). At the end of the experiment, the percentage of active nematodes was reduced to about 30\%, whatever the bacterial concentration. The activity of nematodes was also decreased in the presence of paenimyxin (Fig. 5B). From 48 h, there was a dose- and time-dependent inhibition of the nematode activity. At $120 \mathrm{~h}$, the activity of nematodes was practically zero in presence of paenimyxin at $50 \mu \mathrm{g} \mathrm{ml}^{-1}$ and strongly decreased at 2 and $10 \mu \mathrm{g} \mathrm{ml}^{-1}$.

\subsection{Expression of defense-related grapevine genes}

The expression of genes encoding phenylalanine ammonia lyase $(P A L)$, proteinase inhibitor $(P I N)$, and glutathione-S-transferase (GST) was unaffected by the presence of $X$. index and/or Paenibacil- lus sp. strain B2 (Fig. 6). The expression of the stilbene synthase 1 (STS) gene was slightly induced in the presence of $X$. index whereas it was not modified in presence of the bacteria (Fig. 6, Table 3). Interestingly, expression of the gene encoding chitinase $1 \mathrm{~b}(\mathrm{CHI})$ was significantly induced in response to co-inoculation by $X$. index and Paenibacillus sp. strain B2, but not for inoculation with the bacterium or $X$. index alone. The response was similar for the expression of the lipoxygenase ( $L O X)$ gene, except that inoculation with $X$. index alone slightly enhanced the gene expression (Table 3).

The expression of the nematode "resistant" genes Hero and $H_{s} l^{\text {pro-1 }}$ is presented in Fig. 7. Hero expression was activated in X. index-inoculated plants, although the expression was slightly reduced in the presence of Paenibacillus sp. strain B2. Conversely, $\mathrm{Hs}^{\text {pro-1 }}$ was slightly induced in response to co-inoculation with $X$. index and the bacteria.
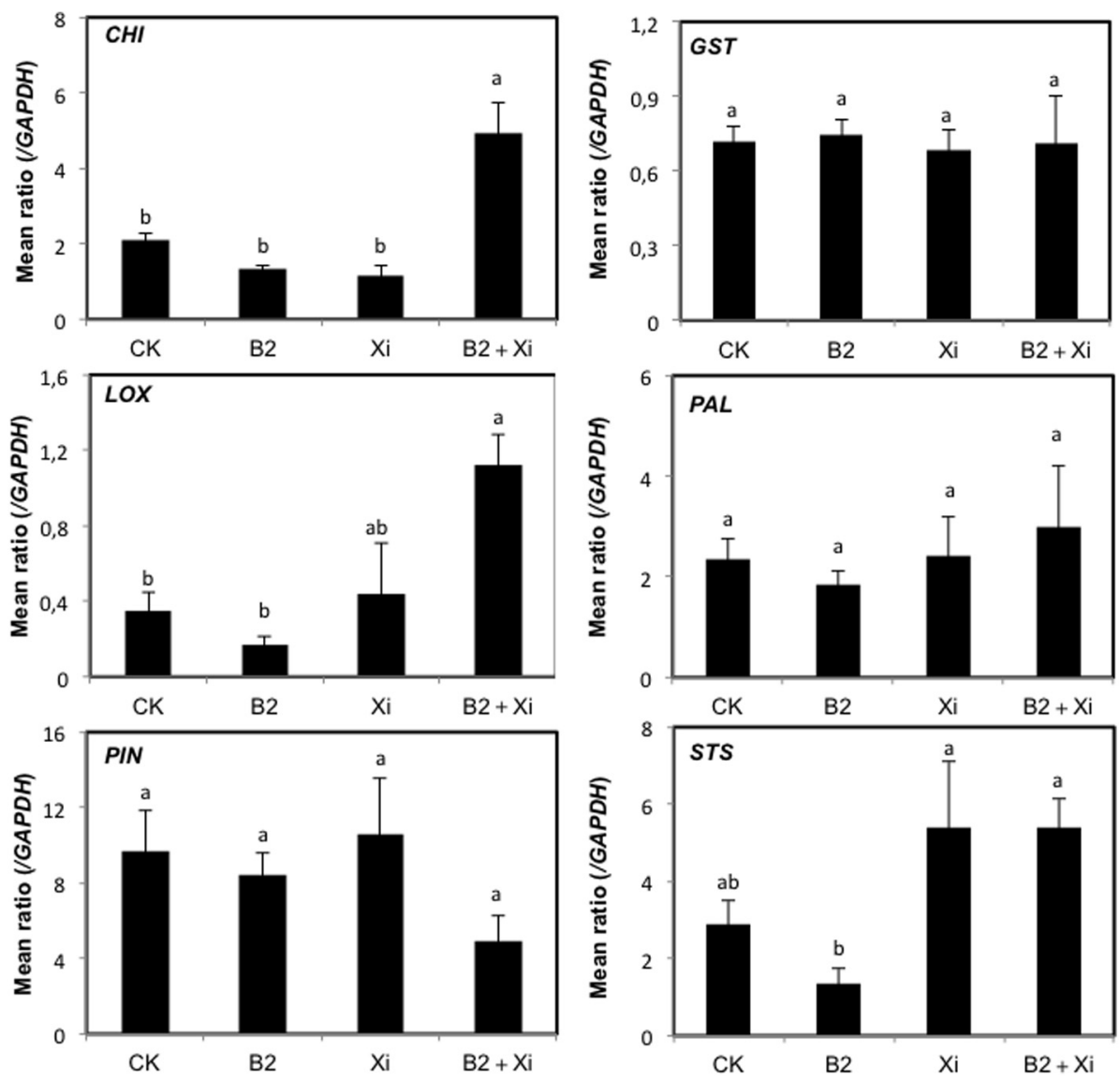

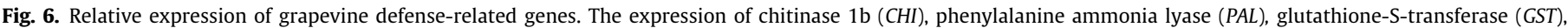

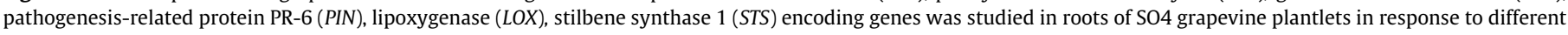

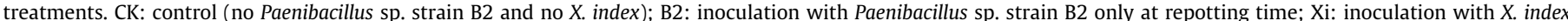

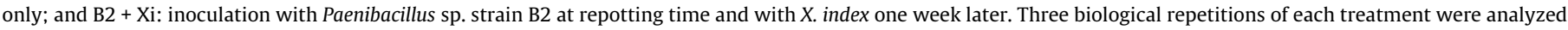
at 35 days after inoculation with $X$. index.

Table 3

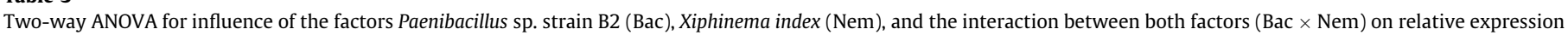

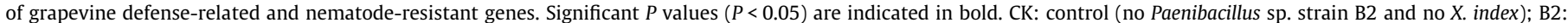

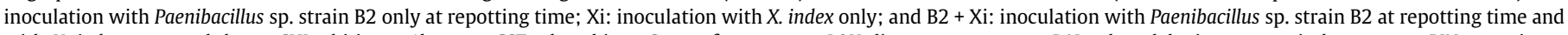

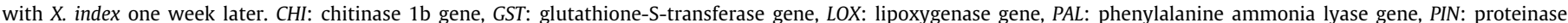

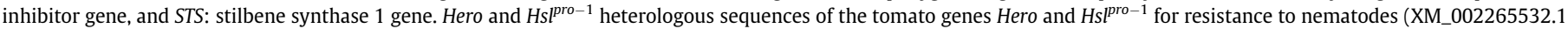
and XM_002268530.1).

\begin{tabular}{|c|c|c|c|c|c|c|c|c|}
\hline Factors & $\mathrm{CHI}$ & GST & LOX & $P A L$ & PIN & STS & HERO & $H s 1^{\text {pro-1 }}$ \\
\hline Bac & 0.003 & 0.774 & 0.162 & 0.958 & 0.076 & 0.377 & 0.852 & 0.020 \\
\hline Nem & 0.006 & 0.738 & 0.014 & 0.337 & 0.450 & 0.004 & 0.028 & 0.001 \\
\hline $\mathrm{Bac} \times \mathrm{Nem}$ & $<0.001$ & 0.987 & 0.029 & 0.392 & 0.220 & 0.369 & 0.080 & 0.360 \\
\hline
\end{tabular}



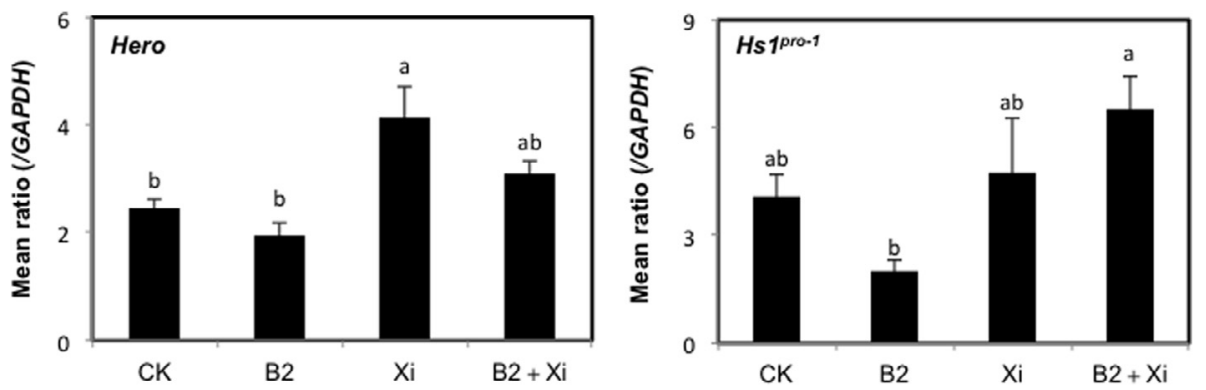

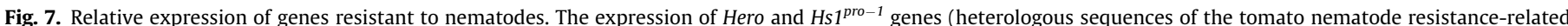

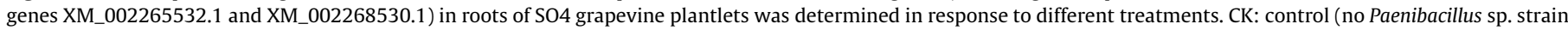

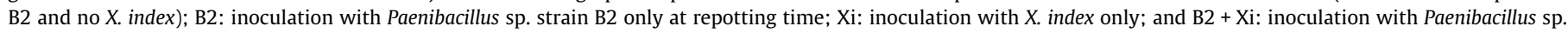
strain B2 at repotting time and with $X$. index one week later. Three repeats of each treatment were analyzed at 35 days after inoculation with $X$. index.

\section{Discussion}

The results obtained here clearly show that the bacterium Paenibacillus sp. strain B2 can inhibit development of the fungal pathogen $B$. cinerea in vitro, and affect activity of the ectoparasitic nematode $X$. index in vitro as well as in planta. Previous in vitro studies have reported inhibition of mycelial growth also of Phytophthora parasitica and Fusarium oxysporum by Paenibacillus sp. strain B2 (Budi et al., 1999). The genus Paenibacillus includes several species producing active compounds able to inhibit plant pathogens (Ongena and Jacques, 2008). For example, Paenibacillus polymyxa strain E681 has been used against a complex of soilborne sesame diseases (Ryu et al., 2006) and, more recently, Kim et al. (2016) reported the antagonistic activity of $P$. polymyxa APEC128 against two Colletotrichum species responsible for apple anthracnose. Antagonistic activity of $P$. polymyxa has also been demonstrated against hatching and penetration of the root-knot nematode Meloidogyne javanica (Siddiqui et al., 2007). Treatment of Arabidopsis thaliana with Paenibacillus alvei K165 was shown to protect against Verticillium dahliae by triggering ISR (Gkizi et al., 2016). All these observations suggest that the genus Paenibacillus has a broad spectrum of antagonistic activity, and therefore could be of potential interest for the biological control of different phytopathogens.

The antagonistic activity of Paenibacillus sp. strain B2 towards phytopathogens involves extracellular chitinolytic, cellulolytic, proteolytic and pectinolytic enzyme activities (Budi et al., 2000), and other substances (Budi et al., 1999) like paenimyxin (Selim et al., 2005, 2010). Paenimyxin, which consists of a mixture of polymyxins or polymyxin-related peptides (Selim et al., 2005), may act by binding to microbial lipopolysaccharides with an irreversible obstruction of membrane permeability, as do other antagonistic factors (Ongena and Jacques, 2008; Budi et al., 2000). Purified paenimyxin has inhibiting activity against bacteria, fungi and oomycetes (Selim et al., 2005). The present study clearly shows that it also directly inhibits the growth of $B$. cinerea, as well as the zoospore mobility and development of $P$. viticola.

Some biocontrol agents or their metabolites reduce disease incidence by activation of defense systems in the host plant (Ongena et al., 2005; Jourdan et al., 2009), and some rhizobacteria or their metabolites can induce systemic resistance (ISR, van Loon et al., 1998; Ongena et al., 2007). In the present study, no defense gene activation was detected in the roots of grapevine plants treated by Paenibacillus sp. strain B2 alone. However, $\mathrm{CHI}$ and LOX genes were activated with decreased $X$. index activity in response to coinoculation of the bacterium and the nematode, although the low expression of the resistance genes $\mathrm{Hs}^{\text {pro-1 }}$ and Hero (Sobczak et al., 2005) suggest that the enhanced grapevine resistance was not related to these specific resistance genes. It would be interest- ing to analyse the kinetics of defense gene expression in leaves and roots treated with Paenibacillus sp. strain B2 to gain insight into the molecular mechanisms of the antagonistic activity of the bacterium in grapevine. Selim et al. (2010) have reported that paenimyxin elicits the production of hydrogen peroxide $\left(\mathrm{H}_{2} \mathrm{O}_{2}\right)$ and upregulates several defense-related genes in cell suspensions of the model legume Medicago truncatula, and Lee et al. (2013) observed that fusaricidin, a cyclic depsipeptide from $P$. polymyxa E681, significantly decreased the severity of red-pepper Phytophthora blight by the induction of systemic resistance. However, in the present bioassays with $P$. viticola, paenimixin application by droplets onto leaf discs prior to oomycete inoculation (to detect defense elicitor activity) did not induce resistance against downy mildew of grapevine tissues. Conversely, addition of paenimyxin directly to $P$. viticola zoospores significantly decreased disease development, suggesting a direct action of this antagonistic peptide. Application of paenimyxin by flotation prior to pathogen inoculation had a slight effect on disease development, compared to application by droplets, but this might be explained by a direct effect of paenimyxin which had accumulated within leaf discs against $P$. viticola during the first stages of pathogen development.

Previously researches showed that Paenibacillus can promote plant development via the production of the phytohormone indole-3-acetic acid (IAA), biological nitrogen fixation, phosphate solubilization, and siderophore secretion which enables iron acquisition (Fernandes et al., 2014; Zhou et al., 2016). Inoculation of grapevine plants with Paenibacillus sp. strain B2 promoted root and shoot biomass, while reducing nematode root infection and decreasing nematode numbers in soil. Budi et al. (1999) have previously shown that Paenibacillus sp. strain B2 promotes tomato root growth, but has no effect on shoot growth, while inhibiting development of $P$. parasitica. These observations are consistent with a role of Paenibacillus as a PGPR (Venkadasamy et al., 2010).

Altogether, the present and previous data demonstrate that Paenibacillus sp. strain B2 and paenimyxin could be effective in strategies to control grapevine pathogens.

\section{Author contribution}

M.A., V.G.-P. Z.H., S.G., X.L., and D.v.T. planned and designed the research. Z.H., L.F., and O.C. performed experiments, Z.H., A.D., D.W. and B.C. analyzed data; Z.H., M.A., and V.G.-P. wrote the manuscript.

\section{Acknowledgments}

The authors are grateful to A. Manga for assistance in producing purified paenimyxin. This research was supported by the Conseil 
Régional de Bourgogne, France (Grant number 079201A AO40S3619), National Natural Science Foundation of China (Grant number 41571250) and the China Scholarship Council (Grant to $\mathrm{ZH})$.

\section{References}

Aballay, E., Flores, P., Insunza, V., 2001. Nematicidal effect of eight plant species on Xiphinema americanum sensu lato in Vitis vinifera, var. Cabernet Sauvignon in Chile. Nematropica 31, 95-102.

Abawi, G.S., Widmer, T.L., 2000. Impact of soil health management practices on soilborne pathogens, nematodes and root diseases of vegetable crops. Appl. Soil Ecol. 15, 37-47.

Allègre, M., Daire, X., Heloir, M.C., Trouvelot, S., Mercier, L., Adrian, M., Pugin, A. 2007. Stomatal deregulation in Plasmopara viticola-infected grapevine leaves New Phytol. 173, 832-840.

Andret-Link, P., Schmitt-Keichinger, C., Demangeat, G., Komar, V., Fuchs, M., 2004 The specific transmission of Grapevine fanleaf virus by its nematode vector Xiphinema index is soley determined by the viral coat protein. Virology 320, 12 22.

Aziz, A., Poinssot, B., Daire, X., Adrian, M., Bezier, A., Lambert, B., Joubert, J.M., Pugin, A., 2003. Laminarin elicits defense responses in grapevine and induces protection against Botrytis cinerea and Plasmopara viticola. Mol. Plant Microbe Interact. 16, 1118-1128.

Barker, K.R., Koenning, S.R., 1998. Developing sustainable systems for nematode management. Annu. Rev. Phytopathol. 36, 165-205.

Bessire, M., Chassot, C., Jacquat, A.C., Humphry, M., Borel, S., Petetot, J.M.C., Metraux, J.P., Nawrath, C., 2007. A permeable cuticle in Arabidopsis leads to a strong resistance to Botrytis cinerea. EMBO J. 26, 2158-2168.

Bloemberg, G.V., Lugtenberg, B.J.J., 2001. Molecular basis of plant growth promotion and biocontrol by rhizobacteria. Curr. Opin. Plant Biol. 4, 343-350.

Brunetto, G., Miotto, A., Ceretta, C.A., Schmitt, D.E., Heinzen, J., de Moraes, M.P. Canton, L., Tiecher, T.L., Comin, J.J., Girotto, E., 2014. Mobility of copper and zinc fractions in fungicide-amended vineyard sandy soils. Arch. Agron. Soil Sci. 60 609-624.

Budi, S.W., van Tuinen, D., Arnould, C., Dumas-Gaudot, E., Gianinazzi-Pearson, V., Gianinazzi, S., 2000. Hydrolytic enzyme activity of Paenibacillus sp. strain B2 and effects of the antagonistic bacterium on cell integrity of two soil-borne pathogenic fungi. Appl. Soil Ecol. 15, 191-199.

Budi, S.W., van Tuinen, D., Martinotti, G., Gianinazzi, S., 1999. Isolation from the Sorghum bicolor mycorrhizosphere of a bacterium compatible with arbuscula mycorrhiza development and antagonistic towards soilborne fungal pathogens. Appl. Environ. Microbiol. 65, 5148-5150.

Busam, G., Kassemeyer, H.H., Matern, U., 1997. Differential expression of chitinases in Vitis vinifera L. responding to systemic acquired resistance activators or fungal challenge. Plant Physiol. 115, 1029-1038.

Coiro, M.I., Brown, D.J.F., 1984. The status of some plants as hosts for fou populations of Xiphinema index (Nematoda: Dorylaimida). Rev. Nematol. 7 . 283-286.

Cook, R.J., 2000. Advances in plant health management in the twentieth century. Annu. Rev. Phytopathol. 38, 95-116.

Czechowski, T., Bari, R.P., Stitt, M., Scheible, W.R., Udvardi, M.K., 2004. Real- time RT-PCR profiling of over 1400 Arabidopsis transcription factors: unprecedented sensitivity reveals novel root- and shoot-specific genes. Plant J. 38, 366-379.

Degenkolb, T., Vilcinskas, A., 2016a. Metabolites from nematophagous fungi and nematicidal natural products from fungi as an alternative for biological control. Part I: metabolites from nematophagous ascomycetes. Appl. Microbiol. Biotechnol. 100, 3799-3812.

Degenkolb, T., Vilcinskas, A., 2016b. Metabolites from nematophagous fungi and nematicidal natural products from fungi as alternatives for biological control. Part II: metabolites from nematophagous basidiomycetes and nonnematophagous fungi. Appl. Microbiol. Biotechnol. 100, 3813-3824.

Demangeat, G., Voisin, R., Minot, J.C., Bosselut, N., Fuchs, M., Esmenjaud, D., 2005. Survival of Xiphinema index in vineyard soil and retention of Grapevine fanlea virus over extended time in the absence of host plants. Phytopathology 95 1151-1156.

Edder, P., Ortelli, D., Viret, O., Cognard, E., De Montmollin, A., Zali, O., 2009. Control strategies against grey mould (Botrytis cinerea Pers.: Fr) and corresponding fungicide residues in grapes and wines. Food Addit. Contam. Part A 26, 719 725.

Elmer, P.A.G., Reglinski, T., 2006. Biosuppression of Botrytis cinerea in grapes. Plant. Pathol. 55, 155-177.

Fernandes, G.D.C., Trarbach, L.J., de Campos, S.B., Beneduzi, A., Passaglia, L.M.P. 2014. Alternative nitrogenase and pseudogenes: unique features of the Paenibacillus riograndensis nitrogen fixation system. Res. Microbiol. 165, 571-580.

Gkizi, D., Lehmann, S., L’Haridon, F., Serrano, M., Paplomatas, E.J., Metraux, J.-P. Tjamos, S.E., 2016. The innate immune signaling system as a regulator of disease resistance and induced systemic resistance activity against Verticillium dahliae. Mol. Plant Microbe. Int. 29, 313-323.

Gu, L., Bai, Z., Jin, B., Zhang, J., Li, W., Zhuang, G., Zhang, H., 2010. Production of a newly isolated Paenibacillus polymyxa biocontrol agent using monosodium glutamate wastewater and potato wastewater. J. Environ. Sci. 22, 1407-1412.
Han, J., Gao, P., Zhao, S., Bie, X., Lu, Z., Zhang, C., Lv, F., 2017. ITRAQ-based proteomic analysis of LI-F type peptides produced by Paenibacillus polymyxa JSa-9 mode of action against Bacillus cereus. J. Proteomics 150, 130-140.

Hahn, M., 2014. The rising threat of fungicide resistance in plant pathogenic fungi: Botrytis as a case study. J. Chem. Biol. 7 (4), 133-141.

Hao, Z., Fayolle, L., van Tuinen, D., Chatagnier, O., Li, X., Gianinazzi, S., GianinazziPearson, V., 2012. Local and systemic mycorrhiza-induced protection against the ectoparasitic nematode Xiphinema index involves priming of defence gene responses in grapevine. J. Exp. Bot. 63, 3657-3672.

Jourdan, E., Henry, G., Duby, F., Dommes, J., Barthelemy, J.P., Thonart, P., Ongena, M., 2009. Insights into the defense-related events occurring in plant cells following perception of surfactin-type lipopeptide from Bacillus subtilis. Mol. Plant Microbe Interact. 22, 456-468.

Kim, Y.S., Balaraju, K., Jeon, Y., 2016. Biological control of apple anthracnose by Paenibacillus polymyxa APEC128, an antagonistic rhizobacterium. Plant Pathol. J. 32, 251-259.

Lee, S.H., Cho, Y.E., Park, S.H., Balaraju, K., Park, J.W., Lee, S.W., Park, K., 2013. An antibiotic fusaricidin: a cyclic depsipeptide from Paenibacillus polymyxa E681 induces systemic resistance against Phytophthora blight of red-pepper. Phytoparasitica 41, 49-58.

Leroch, M., Kretschmer, M., Hahn, M., 2011. Fungicide resistance phenotypes of Botrytis cinerea isolates from commercial vineyards in south west Germany. J. Phytopathol. 159, 63-65.

Martelli, G., 2012. Grapevine virology highlights 2010-2012. In: Foundation Plant Services, University of California, Davis, CA, USA, Proceedings of 17th Congress of the International Council for the Study of Virus and Virus-like Diseases of the Grape- vine (ICVG), 13-31.

Murashige, T., Skoog, F., 1962. A revised medium for rapid growth and bio assays with tobacco tissue cultures. Physiol. Plant. 15, 473-497.

Nanni, I.M., Pirondi, A., Mancini, D., Stammler, G., Gold, R., Ferri, I., Brunelli, A., Collina, M., 2016. Differences in the efficacy of carboxylic acid amide fungicides against less sensitive strains of Plasmopara viticola. Pest Manag. Sci. 72, 15371539.

Ongena, M., Duby, F., Jourdan, E., Beaudry, T., Jadin, V., Dommes, J., Thonart, P., 2005. Bacillus subtilis M4 decreases plant susceptibility towards fungal pathogens by increasing host resistance associated with differential gene expression. Appl. Microbiol. Biotechnol. 67, 692-698.

Ongena, M., Jacques, P., 2008. Bacillus lipopeptides: versatile weapons for plant disease biocontrol. Trends Microbiol. 16, 115-125.

Ongena, M., Jourdan, E., Adam, A., Paquot, M., Brans, A., Joris, B., Arpigny, J.-L., Thonart, P., 2007. Surfactin and fengycin lipopeptides of Bacillus subtilis as elicitors of induced systemic resistance in plants. Environ. Microbiol. 9, 10841090.

Pezet, R., Gindro, K., Viret, O., Richter, H., 2004. Effects of resveratrol, viniferins and pterostilbene on Plasmopara viticola zoospore mobility and disease development. Vitis 43, 145-148.

Reid, K.E., Olsson, N., Schlosser, J., Peng, F., Lund, S.T., 2006. An optimized grapevine RNA isolation procedure and statistical determination of reference genes for real-time RT-PCR during berry development. BMC Plant Biol. 6.

Ryu, C.M., Kim, J., Choi, O., Kim, S.H., Park, C.S., 2006. Improvement of biological control capacity of Paenibacillus polymyxa E681 by seed pelleting on sesame. Biol. Control 39, 282-289.

Sang, M.K., Kim, E.N., Han, G.D., Kwack, M.S., Jeun, Y.C., Kim, K.D., 2014. Primingmediated systemic resistance in cucumber induced by Pseudomonas azotoformans GC-B19 and Paenibacillus elgii MM-B22 against Colletotrichum orbiculare. Phytopathology 104, 834-842.

Saophuong, N., Xuan Hon, N., Naing, K.W., Lee, Y.S., Kim, K.Y., 2014. Insecticidal potential of Paenibacillus elgii hoa73 and its combination with organic sulfur pesticide on diamondback moth, Plutella xylostella. J. Korean Soc. Appl. Biol. Chem. 57, 181-186.

Schouteden, N., De Waele, D., Panis, B., Vos, C.M., 2015. Arbuscular mycorrhizal fungi for the biocontrol of plant-parasitic nematodes: a review of the mechanisms involved. Front. Microbiol. 6.

Selim, S., Martin-Laurent, F., Rouard, N., Gianinazzi, S., van Tuinen, D., 2007. Impact of a new biopesticide produced by Paenibacillus sp. strain B2 on the genetic structure and density of soil bacterial communities. Pest Manag. Sci. 63, 269275.

Selim, S., Negrel, J., Govaerts, C., Gianinazzi, S., van Tuinen, D., 2005. Isolation and partial characterization of antagonistic peptides produced by Paenibacillus sp. strain B2 isolated from the sorghum mycorrhizosphere. Appl. Environ. Microbiol. 71, 6501-6507.

Selim, S., Negrel, J., Wendehenne, D., Ochatt, S., Gianinazzi, S., van Tuinen, D. 2010 Stimulation of defense reactions in Medicago truncatula by antagonistic lipopeptides from Paenibacillus sp. strain B2. Appl. Environ. Microbiol. 76, $7420-7428$

Shoresh, M., Harman, G.E., Mastouri, F., 2010. Induced systemic resistance and plant responses to fungal biocontrol agents. Annu. Rev. Phytopathol. 48, 21-43.

Siddiqui, Z.A., Baghel, G., Akhtar, M.S., 2007. Biocontrol of Meloidogyne javanica by Rhizobium and plant growth-promoting rhizobacteria on lentil. World J. Microbiol. Biotechnol. 23, 435-441.

Sobczak, M., Avrova, A., Jupowicz, J., Phillips, M.S., Ernst, K., Kumar, A., 2005. Characterization of susceptibility and resistance responses to potato cyst nematode (Globodera spp.) infection of tomato lines in the absence and presence of the broad-spectrum nematode resistance Hero gene. Mol. Plant Microbe Interact. 18, 158-168. 
Sparvoli, F., Martin, C., Scienza, A., Gavazzi, G., Tonelli, C., 1994. Cloning and molecular analysis of structural genes involved in flavonoid and stilbene biosynthesis in grape (Vitis vinifera L.). Plant Mol. Biol. 24, 743-755.

Thorne, G., Allen, M.W., 1950. Paratylenchus hamatus n. sp. and Xiphinema index n. sp., two nematodes associated with fig roots with a note on Paratylenchus anceps Cobb. Proc. Helminthol. Soc. W. 17, 27-35.

Trouvelot, S., Varnier, A.L., Allegre, M., Mercier, L., Baillieul, F., Arnould, C., Gianinazzi-Pearson, V., Klarzynski, O., Joubert, J.M., Pugin, A., Daire, X., 2008. A beta-1,3 glucan sulfate induces resistance in grapevine against Plasmopara viticola through priming of defense responses, including HR-like cell death. Mol. Plant Microbe Interact. 21, 232-243.

van Loon, L.C., Bakker, P., Pieterse, C.M.J., 1998. Systemic resistance induced by rhizosphere bacteria. Annu. Rev. Phytopathol. 36, 453-483.
Venkadasamy, G., Murugesan, S., Vellaichamy, M., Upendra, K., Praniita, B. Vikas, S., Kannepalli, A., 2010. Bacillus and Paenibacillus spp.: potential PGPR for sustainable agriculture. In: Maheshwari, D.K. (Ed.), Plant Growth and Health Promoting Bacteria. Springer-Verlag, Berlin Heidelberg, pp. 333364.

Xu, K., Riaz, S., Roncoroni, N.C., Jin, Y., Hu, R., Zhou, R., Walker, M.A., 2008. Genetic and QTL analysis of resistance to Xiphinema index in a grapevine cross. Theor Appl. Genet. 116, 305-311.

Zhou, C., Guo, J., Zhu, L., Xiao, X., Xie, Y., Zhu, J., Ma, Z., Wang, J., 2016. Paenibacillus polymyxa BFKC01 enhances plant iron absorption via improved root systems and activated iron acquisition mechanisms. Plant Physiol. Biochem. 105, 162 173. 